\title{
Veno-venous extracorporeal membrane oxygenation in a patient with severe acute respiratory failure - case report
}

\author{
Bartosz Kubisa ${ }^{1}$, Paweł Łukasz Dec ${ }^{2}$, Anna Justyna Lesińska ${ }^{3}$, Anna Bocheńska ${ }^{4}$, Piotr Wasilewski ${ }^{5}$, \\ Grzegorz Feldyk ${ }^{5}$, Anna Kubisa ${ }^{6}$, Jarosław Pieróg ${ }^{1}$, Michał Bielewicz ${ }^{1}$, Tomasz Grodzki ${ }^{1}$
}

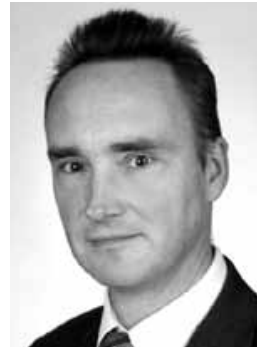

${ }^{1}$ Department of Thoracic Surgery and Transplantation, Pomeranian Medical University in Szczecin, Poland

2Department of General and Hand Surgery, Pomeranian Medical University, Szczecin, Poland

${ }^{3}$ Department of Invasive Cardiology, District Hospital in Szczecin, Poland

${ }^{4}$ Dr A. Sokołowski Specialty Hospital, Szczecin-Zdunowo, Poland

${ }^{5}$ Department of Intensive Therapy, Prof. A. Sokołowski Regional Pulmonary Hospital, Szczecin-Zdunowo, Poland

${ }^{6}$ Department of Internal Medicine, Prof. A. Sokołowski Regional Pulmonary Hospital, Szczecin-Zdunowo, Poland

Kardiochirurgia i Torakochirurgia Polska 2015; 12 (1): 65-68

\begin{abstract}
Acute respiratory failure resistant to conventional pulmonary therapy often requires intensive medical care. In rare cases, ventilator therapy proves insufficient, and only the option of employing veno-venous extracorporeal membrane oxygenation (ECMO V-V) remains. The present article describes the case of a 23-year-old patient who experienced severe acute respiratory distress syndrome with associated multiple organ failure. The patient was admitted to the pulmonary ward of the Alfred Sokołowski Regional Pulmonary Hospital in Szczecin-Zdunowo with suspected pneumonia of unknown etiology. After the initial 5 days of diagnostics at the pulmonary ward, the patient required a further 97 days of hospital treatment and spent 63 days at the Intensive Care Unit. There, he underwent ECMO $\mathrm{V}-\mathrm{V}$ therapy lasting 22 days, which resulted in the improvement of his arterial blood gas parameters and clinical condition.
\end{abstract}

Key words: ECMO, acute respiratory failure, pneumonia.

\section{Introduction}

Extracorporeal membrane oxygenation (ECMO) is often used in adult patients with severe respiratory failure in the course of pneumonia of various etiology. This technique provides the patient's blood with oxygen and reduces hypercapnia until the lung tissue's ability to perform efficient gas exchange is restored. Extracorporeal membrane oxygenation is indicated if the etiology of acute respiratory failure is reversible, which is not always known at the start of the therapy. The technique is complex and expensive; it requires

\section{Streszczenie}

Ostra niewydolność oddechowa, która nie poddaje się standardowemu leczeniu pulmonologicznemu, często wymaga intensywnej terapii oraz leczenia respiratorem. W rzadkich przypadkach respiratoroterapia bywa niewystarczająca i wtedy ostatnią możliwością pomocy choremu jest zastosowanie żylno-żylnej membranowej oksygenacji pozaustrojowej (veno-venous extracorporeal membrane oxygenation - ECMO V-V). W pracy opisano przypadek 23-letniego pacjenta przyjętego na oddział pulmonologiczny Specjalistycznego Szpitala im. Alfreda Sokołowskiego w Zdunowie z podejrzeniem zapalenia płuc o nieznanej etiologii, u którego wystąpił ciężki ostry zespół niewydolności oddechowej z towarzyszącą niewydolnością wielonarządową. Chory po wstępnej 5-dniowej diagnostyce na oddziale pulmonologicznym wymagał 97 dni pobytu w szpitalu, z czego 63 dni na oddziale intensywnej terapii, gdzie przez 22 doby stosowano ECMO V-V, uzyskując wyrównanie gazometryczne oraz poprawę stanu klinicznego.

Słowa kluczowe: ECMO, ostra niewydolność oddechowa, zapalenie płuc.

the involvement of a qualified team and is burdened with the possibility of a number of complications, such as kidney failure, bacterial pneumonia, sepsis, or serious bleeding. Mortality reaches almost 50\% [1]. In this paper, we present a case of successful ECMO V-V treatment used in a 23-yearold patient with acute respiratory distress syndrome (ARDS).

\section{Case study}

The patient was admitted to the pulmonary ward with progressive dyspnea and increasing respiratory failure rais-

Address for correspondence: Bartosz Kubisa, Department of Thoracic Surgery and Transplantation, Pomeranian Medical University in Szczecin, 11 Sokołowskiego St., 70-891 Szczecin-Zdunowo, Poland, phone: +48 607590 891, fax: +48 9146208 36, e-mail: abkubisa@hotmail.com 
ing the suspicion of pneumonia. His condition was gradually deteriorating. Radiological examination revealed extensive bilateral shadowing on the lower lung fields (Fig. 1). Further examinations revealed the following: oxygen saturation $75.6 \%, \mathrm{pH}$ in blood gas analysis (BGA) 7.48, partial pressure of carbon dioxide $\left(\mathrm{PaCO}_{2}\right) 38.5 \mathrm{mmHg}$, partial pressure of oxygen $\left(\mathrm{PaO}_{2}\right) 41.9 \mathrm{mmHg}$, alanine aminotransferase $474 \mathrm{U} / \mathrm{l}$, aspartate aminotransferase $266 \mathrm{U} / \mathrm{l}$, lactate dehydrogenase $561 \mathrm{U} /$ l. A treatment employing co-trimoxazole, ciprofloxacin, doxycycline, and rifampicin was implemented without achieving clinical improvement. On the $5^{\text {th }}$ day of hospitalization, due to clinical and radiological progression, which presented as massive atelectasis of both lungs, left-sided pneumothorax, and mediastinal shift to the right (Fig. 2), the patient was transferred to the intensive care unit (ICU) with the diagnosis of severe acute respiratory failure. The patient required left pleural drainage, deep sedation (fentanyl, tramadol, midazolam, propofol), and ventilation with the following ventilation options: biphasic positive pressure, fraction of inspired oxygen $\left(\mathrm{FiO}_{2}\right)$ 0.5-0.8, positive end-expiratory pressure (PEEP) $32 / 14 \mathrm{~cm} \mathrm{H}_{2} \mathrm{O}$, and pressure support (PS) $18 \mathrm{cmH}_{2} \mathrm{O}$. An improvement was achieved in terms of oxygen pressure in the arterial blood $\left(\mathrm{PaO}_{2}\right.$ $94 \mathrm{mmHg}$ ). Samples for microbiological analysis of the bronchial tree were collected, and treatment with vancomycin and fluconazole was implemented. The viral, fungal and bacterial analyses did not reveal any infection factors. Heart ultrasound examination showed normal cardiac structure, a dilated aorta, no valvular changes, and left ventricular ejection fraction (EF) of $70 \%$. On the $10^{\text {th }}$ day, the patient's respiratory function suddenly deteriorated - chest X-ray examination revealed an expansion of the inflammatory changes involving the lower and middle lobes of both lungs. On the $13^{\text {th }}$ day, due to a deterioration in ventilation, a percutaneous tracheotomy was performed and $\mathrm{FiO}_{2}$ was increased to 0.8-1.0. Subsequently, due to increasing concentrations of potassium ( $8.2 \mathrm{mmol} / \mathrm{l}$ ) and creatinine (up to $1.7 \mathrm{mg} / \mathrm{dl}$ ), renal replacement therapy was introduced. A dialysis cannula

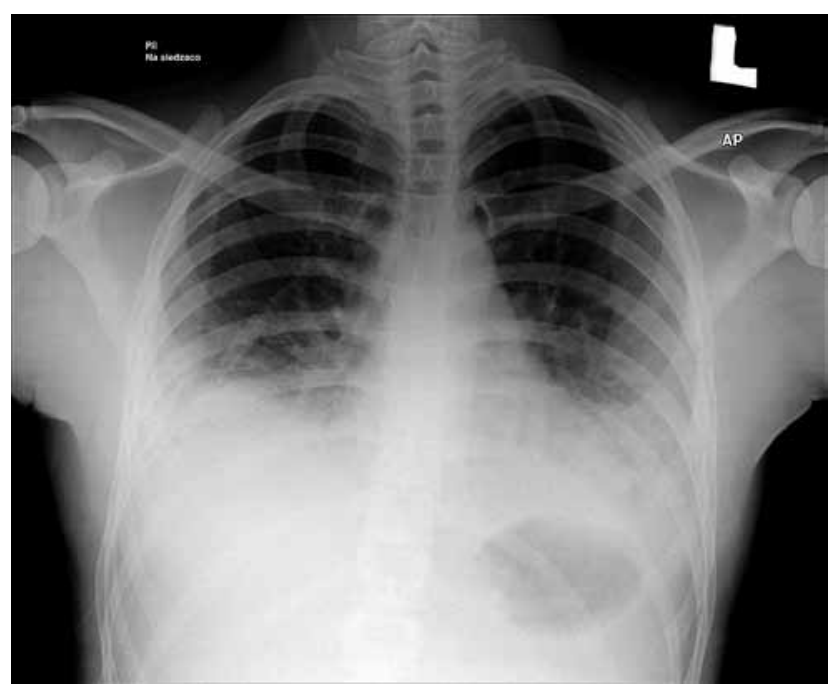

Fig. 1. Chest X-ray - extensive bilateral shadows on the lower lung fields was inserted into the right subclavian vein and continuous veno-venous hemofiltration was commenced. Due to the growing signs of severe respiratory failure and increasing multi-organ hypoxia, ECMO V-V was started on the $11^{\text {th }}$ day of the patient's stay at the ICU. Under general anesthesia, cannulas were introduced into the right internal jugular vein (15 Fr) and the right femoral vein (20 Fr) using the Seldinger technique. Concurrently, heparin began to be administered in a continuous infusion of 2000-2800 units per hour, keeping the clotting time (activated clotting time - ACT) within the range of 130-148 seconds. Initially, the parameters of the ECMO oxygenator were set as follows: $\mathrm{FiO}_{2} 1.0$, blood flow $4 \mathrm{l} / \mathrm{min}$, speed of the centrifugal pump 3000/min, and gas flow $4 \mathrm{l} / \mathrm{min}$. Ultimately, the required gas flow was set at $6-8 \mathrm{l} / \mathrm{min}$. An improvement of the BGA parameters ( $\mathrm{pH}: 7.35, \mathrm{PaO}_{2}: 108 \mathrm{mmHg}, \mathrm{PaCO}_{2}: 54 \mathrm{mmHg}$ ) was achieved on the first day of the ECMO V-V therapy. Over the next two days, based on the normalization of serum potassium $(3.9 \mathrm{mmol} / \mathrm{l})$ and creatinine $(0.8 \mathrm{mg} / \mathrm{dl})$, a decision was made to terminate the dialysis. The ECMO therapy was continued with gas flow at $8 \mathrm{l} / \mathrm{min}$ and with $100 \%$ oxygen in the oxygenator, resulting in the achievement of a gradual improvement in terms of organ oxygenation as well as renal and hepatic function. The oxygen concentration of the ventilator was reduced in a stepwise manner, keeping constant $\mathrm{FiO}_{2}$ 0.5-0.6, PEEP $18 \mathrm{cmH}_{2} \mathrm{O}$, PS $15 \mathrm{cmH}_{2} \mathrm{O}$ in assisted/controlled breathing. On the $23^{\text {rd }}$ day, respiratory function deteriorated again. The performed X-ray examination revealed bilateral pneumothorax, mediastinal emphysema, and left-sided hemothorax $12 \times 5 \times 6 \mathrm{~cm}$ in size. This was treated with repeat thoracotomy and hematoma removal. The heparin treatment was terminated, and nadroparin was administered in a subcutaneous injection of $2 \times 0.6 \mathrm{mg}$. Pathological examination of lung tissue samples showed active advanced interstitial and subpleural fibrosis, with signs of an interstitial inflammatory process dominated by eosinophil granulocytes, with bronchiolization of distal airspace. Again, microbiological tests failed to determine the etiology of

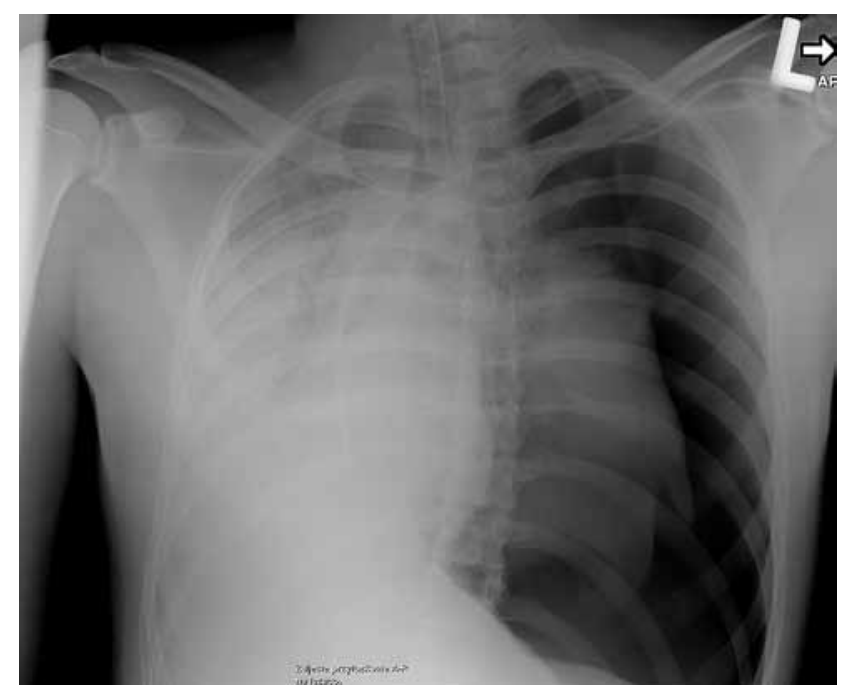

Fig. 2. Chest X-ray - massive atelectasis in both lungs, left-sided pneumothorax and mediastinal shift to the right 
these changes. Periodically, norepinephrine infusion was required during drops in blood pressure. The patient received packed red blood cells, platelet-rich plasma, fresh frozen plasma, and cryoprecipitate. Moreover, blood coagulation factor VIla was introduced, but failed to reduce the bleeding. The concentration levels of coagulation factors VII and IX were normal. On the $16^{\text {th }}$ day of ECMO, the oxygenator had to be replaced due to clot accumulation. In the subsequent days, a slow improvement was observed in terms of respiratory function and chest $X$-ray results. On the $34^{\text {th }}$ day, bleeding into the pleural cavities intensified (5500 $\mathrm{ml}$ per day), requiring surgical coagulation. In view of the inefficiency of the anticoagulation therapy and the increasing manifestation of oxygenator clotting, a decision was made to end the ECMO therapy after 22 days of its duration. The parameters of mechanical ventilation were established at: $\mathrm{FiO}_{2}$ 0.45, PEEP 34/10 $\mathrm{cmH}_{2} \mathrm{O}$, PS $24 \mathrm{cmH}_{2} \mathrm{O}$; blood oxygen saturation was maintained within the range of $90-96 \%$, and satisfactory BGA parameters $\left(\mathrm{pH}: 7.49, \mathrm{PaO}_{2}: 102 \mathrm{mmHg}^{\mathrm{PaCO}}\right.$ : $41 \mathrm{mmHg}$ ) were noted. An improvement of the general condition was achieved, and normal coagulation function was restored (prothrombin time 10 s, Quick's index of 109\%, INR 0.9 , APTT $32 \mathrm{~s}$ ). However, massive bleeding into the left pleural cavity persisted ( $9000 \mathrm{ml}$ from the drains). The ventilator was set in proportional assist ventilation mode with oxygen concentration at $\mathrm{FiO}_{2} 0.3$ and assistance at $50 \%$. On the $68^{\text {th }}$ day after admission, the bleeding stopped. After another two days, the ventilator was disconnected, and the tracheostomy was removed. The patient was breathing spontaneously with an oxygen mask at 2 liters per minute, with $\mathrm{PaO}_{2}$ reaching from 60 to $80 \mathrm{mmHg}$. Despite persistent tachycardia of 100-120 per minute, right ventricular pressure was $40 \mathrm{mmHg}$, and the performed heart ultrasound confirmed good contractility of the cardiac ventricles with EF of $70 \%$.

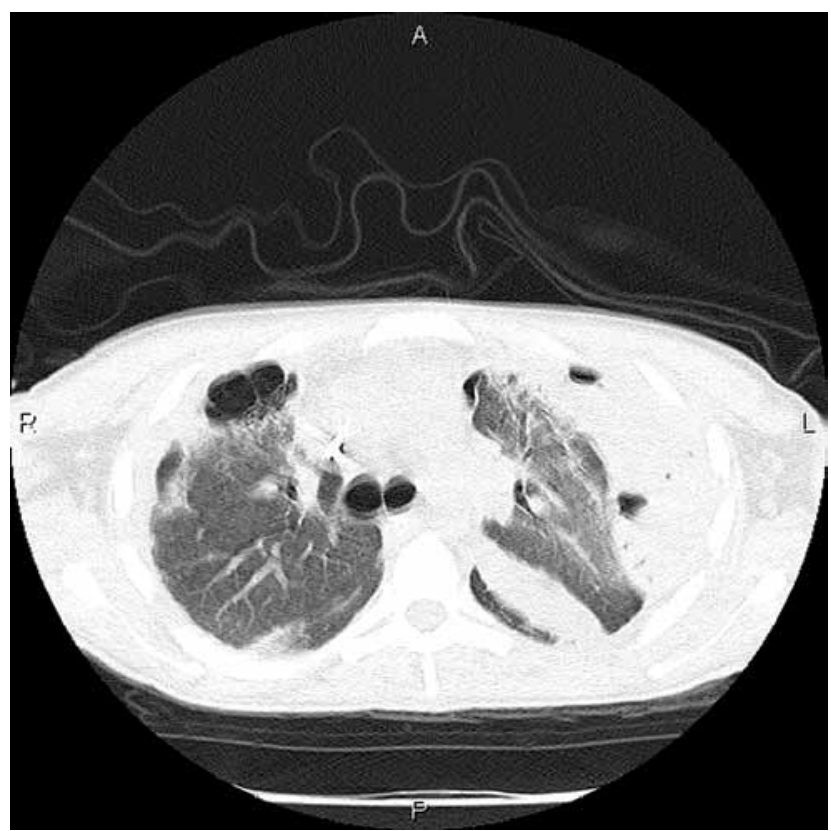

Fig. 3. Chest computed tomography - extensive bilateral groundglass opacities in the lung fields and interstitial fibrosis
The patient was transferred to the Thoracic Surgery Ward in stable condition. Chest computed tomography showed adhesions on the left side, fluid and pneumothorax of $4 \mathrm{~cm}$ along with minor changes on the right side, as well as extensive bilateral ground-glass opacities in the lung fields and a reticular density giving the appearance of interstitial fibrosis (Fig. 3). Conservative treatment and rehabilitation were continued. On the $72^{\text {nd }}$ day, due to increasing bleeding into the left pleural cavity (Fig. 4), the patient was qualified for left-sided thoracotomy, during which lung decortication, marginal lingula resection, and partial rib resection were performed in order to reduce the capacity of the pleural cavity. Throughout the period of hospitalization, the patient required the transfusion of 76 units of packed red blood cells, 9 units of platelets, 38 units of plasma, and 32 units of cryoprecipitate. After 96 days, the patient was discharged home in good general condition, with no fever, and with a recommendation to continue rehabilitation (Figs. 5 and 6).

\section{Discussion}

The main indications for the use of ECMO V-V in adults are: ARDS with oxygenation index $\left(\mathrm{PaO}_{2} / \mathrm{FiO}_{2}\right)<70 \mathrm{mmHg}$, asthmatic state, respiratory disorders due to sepsis, traumatic lung injury, and awaiting for a lung transplant. In many cases, ECMO is an effective therapy, and it offers a chance of survival to an increasing number of patients in whom conventional conservative treatment has failed. However, there are a number of contraindications to its use, including the irreversibility of the pulmonary changes, the existence of potential sources of bleeding preventing the use of heparin, and the lack of the patient's consent. Extracorporeal membrane oxygenation therapy is burdened with a number of complications associated with the patient's critical condition, technical complications including damage of the pump, drains and gauges, clotting in the cannulas, drains and oxygenator, damage of the heat exchangers, air bubbles in the drains, accidental decannulation, and, most importantly, bleeding. Therefore, ECMO

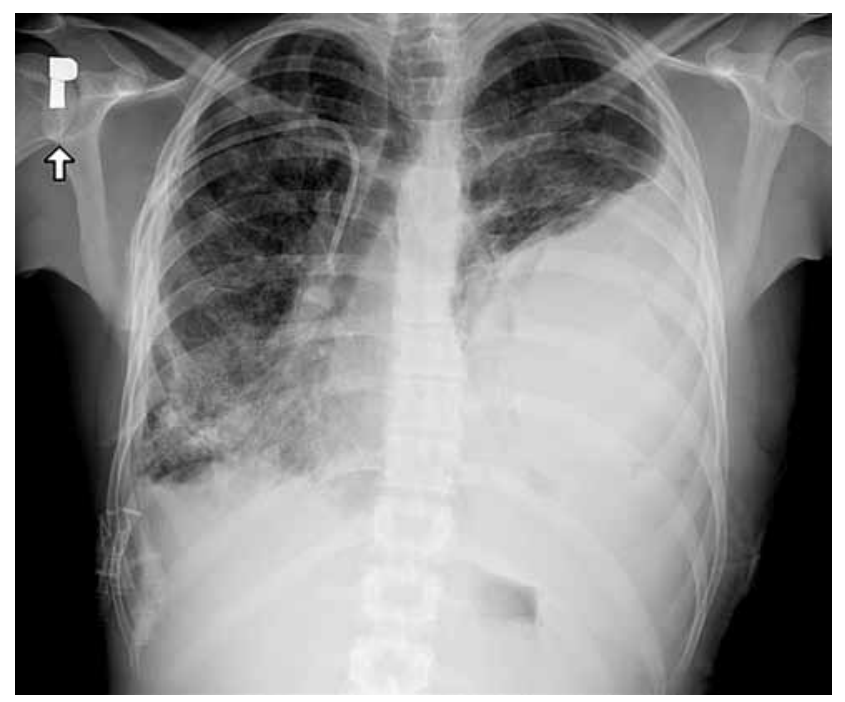

Fig. 4. Chest X-ray - left-sided massive hemothorax 


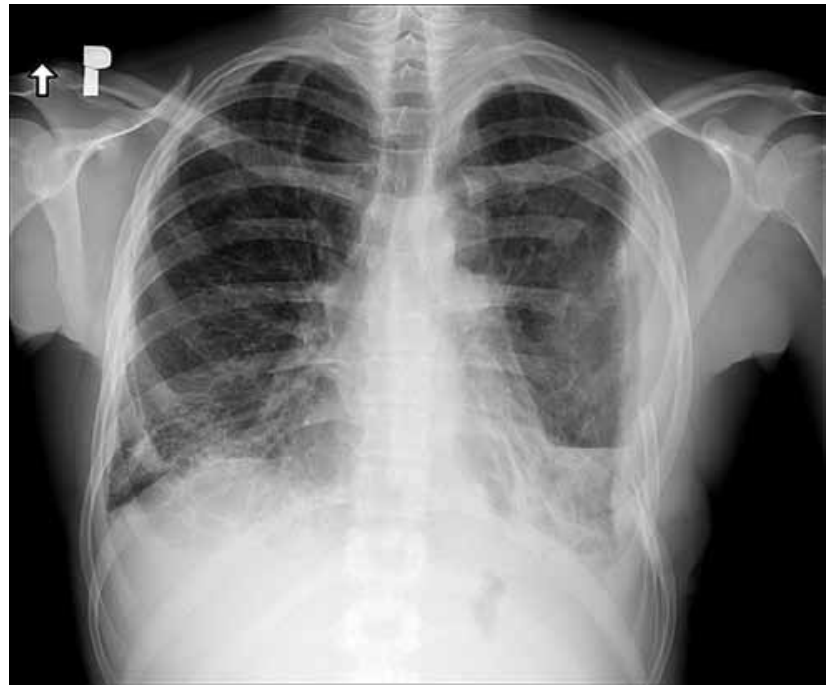

Fig. 5. Chest X-ray before discharge

therapy is not only very difficult to conduct, but also very expensive. In the case described above, the therapeutic team decided to use ECMO V-V in a 23-year-old patient with severe ARDS, achieving a good therapeutic effect. The presented method is utilized in cases of respiratory failure not accompanied by a cardiac component [2]. Extracorporeal membrane oxygenation therapy is successful in the majority of patients, but the contraindications and risk involved require careful consideration [1, 2]. Thus, the indications are limited to conditions where mortality exceeds $80 \%$ without ECMO intervention [3]. The described patient exhibited complications typical for ECMO, such as renal failure requiring hemofiltration (occurring in 52\% of cases), bleeding (33\%), oxygenator dysfunction requiring oxygenator replacement (29\%), venous thrombosis (10\%), and gastrointestinal bleeding (7\%) [1]. Bleeding and pneumothorax are the most common complications requiring surgical treatment in the course of ECMO. Thoracotomy due to complications is required by $3.2 \%$ of all patients undergoing ECMO; of these complications, $75 \%$ are hemorrhagic. Therefore, ECMO therapy should be performed in a thoracic surgery ICU in order to ensure the patient's safety in the event of bleeding [4]. Transporting a patient with ECMO equipment is extremely risky and logistically complicated [5]. Prevention of bleeding complications includes the administration of blood products such as red blood cell concentrates, platelet concentrates, plasma, and preparations of coagulation factors. There are reports of potentially beneficial effects of recombinant coagulation factor VIla used for uncontrolled bleeding in patients treated with ECMO. The positive action focuses on stopping the bleeding without increasing the risk of ECMO clotting, but no conclusive results are available [6]. In the presented case, no clear effect of recombinant factor VIla was observed. In order to prevent complications and monitor the patient's condition, regular cardiac ultrasound is required; it allows the physician to detect thromboembolisms or en-

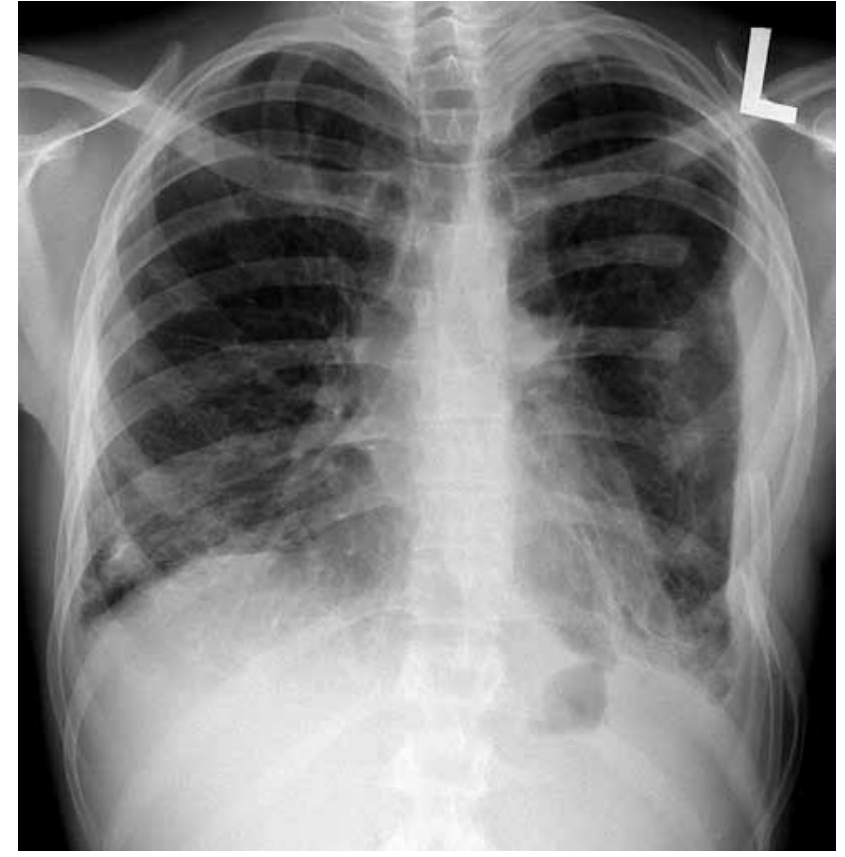

Fig. 6. Chest X-ray 30 days after discharge

docarditis [7]. In the future, ECMO may provide a chance of survival to a much larger number of patients in the state of severe acute respiratory failure, provided that a reduction of ECMO complications is achieved, particularly with regard to bleeding.

\section{Disclosure}

Authors report no conflict of interest.

\section{References}

1. Zangrillo A, Landoni G, Biondi-Zoccai G, Greco M, Greco T, Frati G, Patroniti N, Antonelli M, Pesenti A, Pappalardo F. A meta-analysis of complications and mortality of extracorporeal membrane oxygenation. Crit Care Resusc 2013; 15: 172-178.

2. Roch A, Hraiech S, Masson E, Grisoli D, Forel JM, Boucekine M, Morera P, Guervilly C, Adda M. Outcome of acute respiratory distress syndrome patients treated with extracorporeal membrane oxygenation and brought to a referral center. Intensive Care Med 2014; 40: 74-83.

3. Stöhr F, Emmert MY, Lachat ML, Stocker R, Maggiorini M, Falk V, Wilhelm MJ. Extracorporeal membrane oxygenation for acute respiratory distress syndrome: is the configuration mode an important predictor for the outcome? Interact Cardiovasc Thorac Surg 2011; 12: 676-680.

4. Joshi V, Harvey C, Nakas A, Waller DA, Peek GJ, Firmin R. The need for thoracic surgery in adult patients receiving extracorporeal membrane oxygenation: a 16-year experience. Perfusion 2013; 28: 328-332.

5. Stankiewicz A, Frank M, Dmitruk I, Czudzinowicz K, Teodorowski W, Walicka-Pyłko A, Matulewicz-Gilewicz J, Bernacki A, Juszczyk G, Matlak K, Siemiątkowski A, Sosnowski A, Hirnle T. Skuteczna terapia ostrej niewydolności oddechowej w przebiegu infekcji wirusem grypy A/H1N1 przy użyciu membranowego natleniania pozaustrojowego. Kardiochir Torakochir Pol 2011; 4: 462-465.

6. Repessé X, Au SM, Bréchot N, Trouillet JL, Leprince P, Chastre J, Combes A, Luyt CE. Recombinant factor VIla for uncontrollable bleeding in patients with extracorporeal membrane oxygenation: report on 15 cases and literature review. Crit Care 2013; 17: R55.

7. Platts DG, Sedgwick JF, Burstow DJ, Mullany DV, Fraser JF. The role of echocardiography in the management of patients supported by extracorporeal membrane oxygenation. J Am Soc Echocardiogr 2012; 25: 131-141. 